\title{
THICKNESS DEPENDENCE OF MAGNETIC SWITCHING DYNAMICS OF BARIUM-FERRITE AS A HIGH-DENSITY PERPENDICULAR MAGNETIC STORAGE MEDIA
}

\author{
P. P. Aji ${ }^{1}$, F. S. Rondonuwu², N. A. Wibowo ${ }^{1 *}$ \\ ${ }^{1}$ Department of Physics, Universitas Kristen Satya Wacana, Indonesia \\ 2Department of Physics Education, Universitas Kristen Satya Wacana, Indonesia
}

Received: 17 January 2017. Accepted: 19 June 2017. Published: 1 July 2017

\begin{abstract}
Micromagnetic study of material thickness dependence of Barium-ferrite nano-dot magnetization dynamics has been performed. The used materials characteristics in this research represent the properties of Bariumferrite. Barium-ferrite was modeled as a nano-dot with a surface area of $50 \times 50 \mathrm{~nm} 2$ and its thickness varies from $5 \mathrm{~nm}$ to $100 \mathrm{~nm}$. This nano-dot was simulated using micromagnetic simulator software by solving Landau-Lifshitz-Gilbert equation. According to this study, obtained that the Barium-ferrite nano-dot has excellent thermal stability. Magnetization rate of this nano-dot decreases exponentially with the increase of thickness. The fastest magnetization rate observed in $5 \mathrm{~nm}$ of nano-dot thickness, meanwhile $45 \mathrm{~nm}$ for the slowest rate. Magnetization reversal mode of this Barium-ferrite nano-dot is dominated by domain wall nucleation and propagation. During the propagation of the domain wall, the exchange interaction becomes the main aspect compared to the other contributed energies.
\end{abstract}

\section{ABSTRAK}

Telah dilakukan studi mikromagnetik pengaruh ketebalan material terhadap dinamika magnetisasi nanodot Barium-ferit. Karakteristik bahan yang dipergunakan di dalam penelitian ini mewakili karakteristik dari Barium-ferrite. Penelitian ini menggunakan sampel model berbentuk nano-dot berdimensi $50 \times 50 \mathrm{~nm}^{2}$ dengan variasi ketebalan $5 \mathrm{~nm}-100 \mathrm{~nm}$ yang disimulasikan dengan menggunakan software simulator mikromagnetik dengan menyelesaikan persamaan Landau-Lifshitz-Gilbert. Dari simulasi ini diperoleh bahwa Barium-ferit memiliki kestabilan termal yang baik, hal ini dibuktikan dari besarnya nilai energi tanggul. Diperoleh juga bahwa laju magnetisasi bahan cenderung menurun secara eksponensial seiring dengan meningkatnya ketebalan bahan. Laju magnetisasi yang terbesar terjadi pada ketebalan $5 \mathrm{~nm}$ dan yang terendah pada ketebalan $45 \mathrm{~nm}$. Pola pembalikan magnetisasi nano-dot Barium-ferit didominasi oleh pembentukan dan perambatan dinding-domain. Pada proses perambatan dinding-domain nano-dot Bariumferit, interaksi tukar memiliki pengaruh yang lebih besar dibandingkan penyusun energi yang lain.

(C) 2017 Jurusan Fisika FMIPA UNNES Semarang

Keywords: Domain wall; Magnetic field; Magnetization; Switching field

\section{INTRODUCTION}

Availability of high densities Hard-disk drive is emerging to answer the demand (Kim et al., 2015). In attaining the required densities, the storage unit should be downsized in nanometer (Kim et al., 2007) (Sadnawanto \& Purnama, 2014). This reduction scale causes thermal instability (Wood, 2009)(Budi Purnama,

*Correspondence Address:

Jalan Diponegoro No.52-60, Salatiga

E-mail: nurajiwibowo@gmail.com
Koga, Nozaki, \& Matsuyama, 2009) (Liu et al., 2016) and its information would be lost because of low magnetic energy (Ma \& Liu, 2008). In overcoming this issues, the uses of perpendicular magnetic anisotropy (PMA) material as a storage unit media is required (Waseda et al., 2008) (Alebrand et al., 2012) (Azizah, Trihandaru, \& Wibowo, 2016). The PMA material has tiny domain-wall which ensures more efficient motion during magnetic field induction (Jung, Kim, Lee, Lee, \& Lee, 2008) (Woo et al., 2016). 
Limitation of scale ratio aspect in meeting the required stability can be solved by utilization of PMA material (Purnama et al., 2009). On the other hand, the magnitude of the driven field required to reverse the magnetization of the PMA material is too large so that the extended research on the magnetization dynamics at room temperature should be conducted (Hui, Cheng, Yan, Chen, \& Miao, 2015). The magnetization dynamic is related to the external field either energy which consumed in the magnetization reversal.

The one aspect of this dynamic that important to be investigated is domain wall propagation (Cho, Jung, Cho, \& You, 2015). In the last decades, various researchers have focused on the domain wall movement in the PMA thin-film (Metaxas et al., 2007; Mihai et al., 2013) which was motivated to understand the fundamental physics role of spintronic based devices (Shepley, Rushforth, Wang, Burnell, \& Moore, 2015).

The geometry of ferromagnetic materials significantly affects the performance of various magnetic-based devices (Purnama, Prihanto, \& Artono, 2013). One important aspect of this geometry is the thickness (Hui et al., 2015). In this paper, media thickness as one factor that controls the magnetization dynamics will be investigated numerically through micromagnetic study. As known from the previous research, media thickness plays an important role in the magnetization reversal which correlated to the read-write data (Hou \& Krishnan, 2012) (Zhang, Li, Wang, Nie, \& Guo, 2015). The magnetic material which investigated is Barium-ferrite. The uses of this material have various benefits. Beside of its large magnetic anisotropy, it also has the chemical stability that assures the durability (Lisfi \& Lodder, 2002). The strong magnetic anisotropy is a fundamental feature required as a magnetic storage media with sufficient thermal stability (Shimizu et al., 2012). The purpose of this study is to examine the effect of Bariumferrite thickness on the magnetization reversal characteristic of switching field, magnetization rate, and the dynamics of domain wall propagation.

\section{METHOD}

To solve the magnetization dynamics of Barium-ferrite nano-dot, Equation (1) is used. (Budi Purnama et al., 2009)

$$
\frac{d \mathbf{M}^{i}}{d t}=-|\gamma| \mathbf{M}^{i} \times \mathbf{H}_{\mathrm{eff}}^{i}+\frac{\alpha}{M_{\mathrm{sat}}} \mathbf{M}^{i} \times \frac{d \mathbf{M}^{i}}{d t}
$$

This equation called as Landau-LifshitzGilbert (LLG) equation which the first and second terms respectively are described the gyromagnetic motion of magnetization and the damping factor. This damping cause the magnetization tends to parallel to the effective induced magnetic field. By using LLG equation, magnetization dynamics during exposed to the external magnetic field can be explained. In this equation, $\mathbf{M}$ is the magnetization of the unit-cell, $d t$ is the step integration as large as $0.25 \mathrm{ps}, \mathrm{y}$ is the gyromagnetic ratio as large as $1.76 \times 10^{7} \mathrm{Oe}^{-1} \mathrm{~s}^{-1}$ (Lisfi, 2002), $\alpha$ is the Gilbert damping factor, and $M_{\text {sat }}$ is the saturation of magnetization of nano-dot. $\mathbf{H}_{\text {eff }}$ is the effective induced magnetic field which acts as the resultant of a various factor that sourced from the external magnetic field and internal properties of materials which consist of anisotropy field $\left(\mathbf{H}_{\mathrm{k}}\right)$, demagnetization field $\left(\mathbf{H}_{\mathrm{d}}\right)$, and exchange field $\left(\mathbf{H}_{\mathrm{ex}}\right)$ as given in Eq.(2) (Schrefl, Fidler, Suess, Scholz, \& Tsiantos, 2006) (Herianto, Rondonuwu, \& Wibowo, 2015):

$$
\mathbf{H}_{\text {eff }}=\mathbf{H}_{\mathrm{k}}+\mathbf{H}_{\mathrm{d}}+\mathbf{H}_{\mathrm{ex}}+\mathbf{H}_{\mathrm{ext}}
$$

The effective induced magnetic field which acts as a controller for the magnetic moment is attained from the differential of energy density, $\varepsilon$, of unit cells with respect to magnetic moment as shown in Eq.(3).

$$
\mathbf{H}_{e f f}=-\frac{1}{M_{s}} \frac{d \varepsilon}{d \mathbf{m}}
$$

In this micromagnetic study, Bariumferrite was modeled as a parallel-piped which called as nano-dot with the lateral dimension is $50 \times 50 \mathrm{~nm}^{2}$ with its thickness varies in the range of $5 \mathrm{~nm}$ up to $100 \mathrm{~nm}$. The nano-dot is composed of $15 \times 15$ of unit cells which shown in Fig.1. The unit cell only contains single magnetic moment. Interaction of adjacent unit cells was accommodated in the exchange interaction field. Meanwhile, the nano-dot is assumed as an isolated system. 


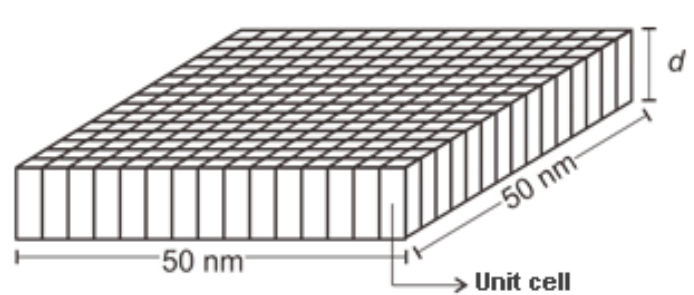

(a)

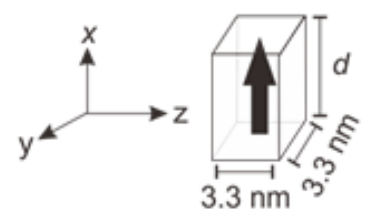

(b)

Figure 1. (a) Nano-dot Barium-ferrite, (b) unit cell (Herianto, Rondonuwu, \& Wibowo, 2015)

The chosen intrinsic magnetic properties were magnetic saturation and damping constant as large as 4800 Gauss and 0.9 respectively (Boardman, 2005). $6.3 \times 10^{-7} \mathrm{erg} / \mathrm{cm}$ and $3.0 \times 10^{6} \mathrm{erg} / \mathrm{cm}^{3}$ of exchange interaction and anisotropy constant respectively (Mansuripur \& Connell, 1984).

In this study, Reduced Barrier Writing (RBW) simulation scheme was used. This scheme worked at room temperature which there was no contribution of thermal field. The magnetic field was exposed to the nano-dot with its magnitude increased linearly from 0 to 2 Tesla for $2.5 \mathrm{~ns}$ as shown in Fig.2. Through this scheme, principal information for magnetization reversal dynamics of Barium-ferrite at room temperature can be observed. Either thermal stability of Barium-ferrite or minimum energy that required to reverse the nano-dot magnetization can be determined. Furthermore, the magnitude of this barrier energy represents thermal stability level of the materials. Low barrier energy leads to the unsustainable recorded data in the magnetic storage media. $60 k_{\mathrm{B}} \mathrm{T}$ is the minimum barrier energy level should be accomplished in order to store the information more than 10 years (Augustine et al., 2011).

The first step of this micromagnetic study is to evaluate the magnitude of the barrier energy. After the prerequisite of thermal stability is attained, the second step is to calculate the minimum magnetic field induction required to exactly switch the magnetic polarization which called as switching field, $H_{\text {swt }}$. The magnitude of
$H_{\text {swt }}$ was obtained by finding the magnitude of the field at which the normalized magnetization equal to zero. The third step is to calculate the magnetization rate. This rate is obtained from the gradient of the normalized magnetization curve.
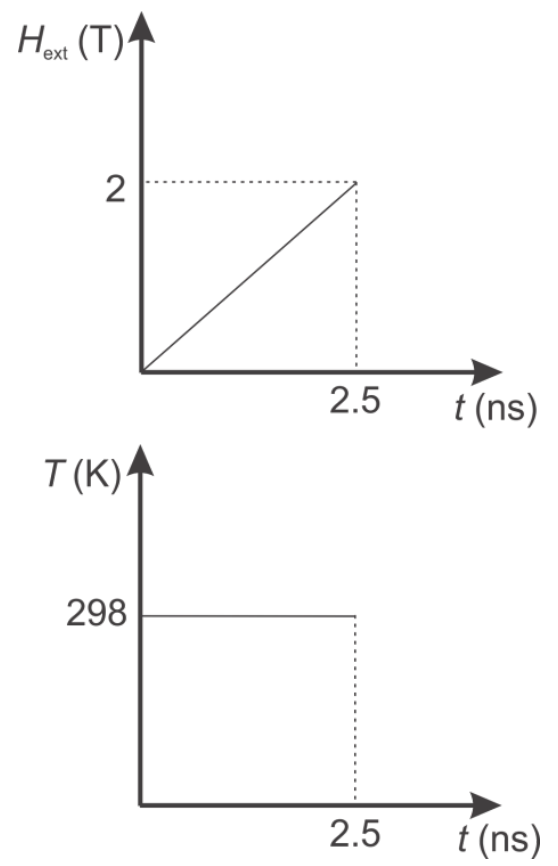

Figure 2. Reduce Barrier Writing scheme (Herianto, Rondonuwu, \& Wibowo, 2015)

\section{RESULTS AND DISCUSSION}

During exposed to the external magnetic field, the nano-dot has energy which composed from various source. This energy was defined as a scalar summation of the Zeeman energy $\left(E_{z}\right)$, exchange energy $\left(E_{\text {ex }}\right)$, the magnetic crystalline-anisotropy energy $\left(E_{K}\right)$, and demagnetization energy $\left(E_{\mathrm{D}}\right)$ as shown in Eq.(4).

$E=E_{\mathrm{z}}+E_{\mathrm{ex}}+E_{\mathrm{K}}+E_{\mathrm{D}}$

The Zeeman energy is the energy of the nano-dot which appears as an interaction of magnetic moment with the external magnetic field. The exchange energy acts as a shortrange interaction between the two neighboring spins. The magnetic crystalline-anisotropy energy of nano-dot is caused by the interaction of spins with the electron orbits which are related to the nano-dot crystallographic structure. Meanwhile, the demagnetization energy is the type of energy which connected to the interaction between magnetic dipole caused the formation of the magnetic domain. (Krone, 2011) 
Energy profile of nano-dot for various thicknesses while exposing by external magnetic field is given by Fig.3(a). These energies are consisting of the two important values, i.e. maximum and minimum. The peak of this barrier energy is achieved at which the magnetization of nano-dot is exactly switched. Meanwhile, minimum energies are the state at which the nano-dot stay in equilibrium. The difference of both values is named as barrier energy, $\Delta E$. This barrier separates the two existing equilibrium state of nano-dot. The first equilibrium state is the condition of nano-dot at initial magnetization (before induced by external field). Meanwhile, the second equilibrium state is the condition at which the nano-dot has been magnetized in the induced field direction. Knowledge of about barrier energy is important. It gives the information of the required energy to reverse the magnetization of particular nanodot. Thickness dependence of energy barrier is shown in Fig.3(b). This barrier highly depends on the thickness of the nano-dot. The energy barrier of the Barium-ferrite nano-dot for various thicknesses are larger than $60 k_{\mathrm{B}} \mathrm{T}$ which means this material is compatible to be used as perpendicular magnetic storage media with excellent thermal stability. This barrier is rising linearly with respect to the increasing of the media thicknesses. The lowest value is obtained for $5 \mathrm{~nm}$ of the thickness with an appropriate barrier as large as $717 k_{\mathrm{B}} \mathrm{T}$. Meanwhile, the largest barrier is observed for $100 \mathrm{~nm}$ of the thickness with $16.700 k_{\mathrm{B}} \mathrm{T}$ of the barrier value.

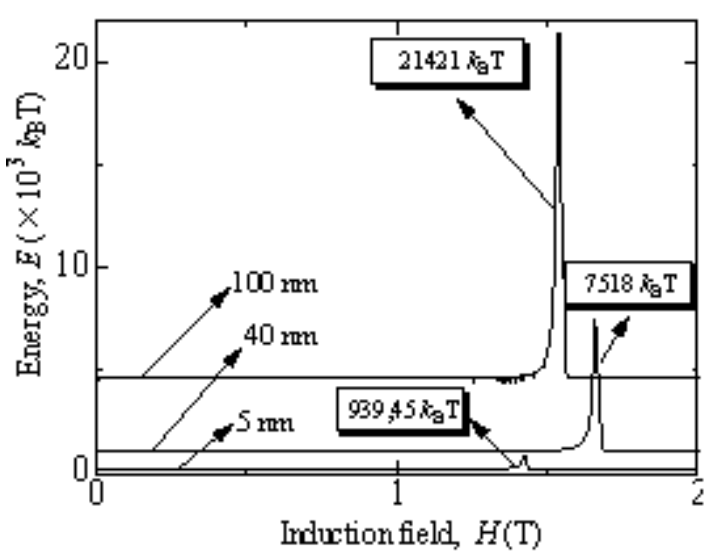

(a)

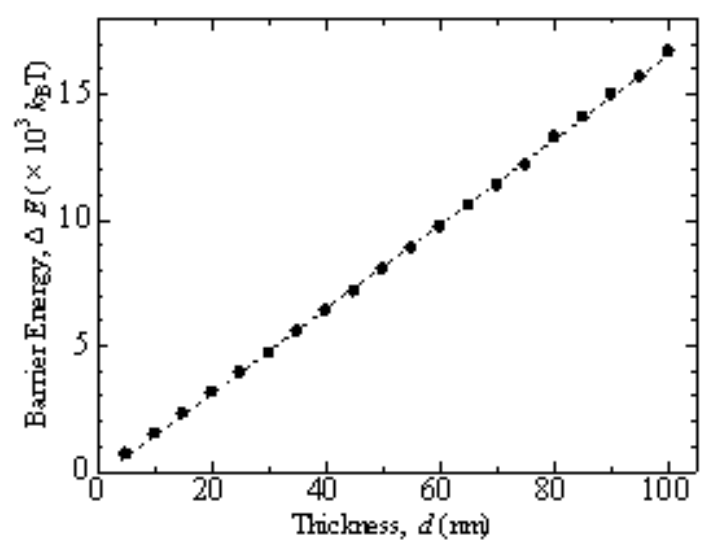

(b)

Figure 3. (a). The energy of Barium-ferrite nano-dot for three different thicknesses $5 \mathrm{~nm}$, $40 \mathrm{~nm}$, and $100 \mathrm{~nm}$, (b). The barrier energy of Barium-ferrite nano-dot for various thicknesses at room temperature.

The magnetization of the Barium-ferrite nano-dot while exposed with 2 Tesla of external magnetic field is shown in Fig.4(a). Before induced by external magnetic field, initial magnetization of nano-dot lie in $(x-)$ axis direction. Then, the nano-dot is induced by an external field which is directed in $(x+)$ direction with its magnitude increase linearly from 0 up to 2 Tesla in 2.5 ns. Magnetization dynamics of nanodot while exposed can be analyzed from the value of normalized magnetization, $M / M_{\text {sat }} . M$ is the real-time magnetization of nano-dot, while $M_{\text {sat }}$ is the saturation of the nano-dot magnetization. This norm-magnetization is equal to 1 at initial magnetization state which indicating both, either magnitude and direction of realtime magnetization are similar to the saturation magnetization of nano-dot. Along with the increasing of induction of magnetic field, this value is decreased. At the zero value of $M l$ $M_{\text {sat' }}$, entire magnetic moments of the nano-dot are perpendicular to its magnetic saturation (no one of the magnetic moments direction is parallels). At this point, the magnetization of nano-dot is exactly to switch. The associated time and induced field at this state are called as switching-time, $t_{\text {swt }}$ and switching field, $H_{\text {swt }}$ respectively. While increasing the induced field, the normalized magnetization will reach -1 . At this value, nano-dot has been perfectly magnetized in line to the induced field; the magnitude of the magnetization is equal to its saturation however the direction is opposite. As observed in Fig.4(a), the switching time is also sensitive to the nano-dot thickness. From the chosen 
thickness samples, nano-dot with $5 \mathrm{~nm}$ of the thickness has the fastest switching time as fast as $1,7825 \mathrm{~ns}$, while the slowest one possessed by nano-dot with $40 \mathrm{~nm}$ of thickness as long as 2,0725 ns.

The impression of the nano-dot thickness to the magnitude of switching field is presented in Fig.4(b). For thickness interval $5 \mathrm{~nm}$ up to $40 \mathrm{~nm}$, the magnitude of $H_{\text {swt }}$ is magnified from $1.43 \mathrm{~T}$ to $1.66 \mathrm{~T}$ along with the increasing of nano-dot thickness. Meanwhile, this field is degraded from 1.66 $\mathrm{T}$ to $1.54 \mathrm{~T}$ along with the enlarging of the thickness in the range of $40 \mathrm{~nm}$ up to $100 \mathrm{~nm}$.

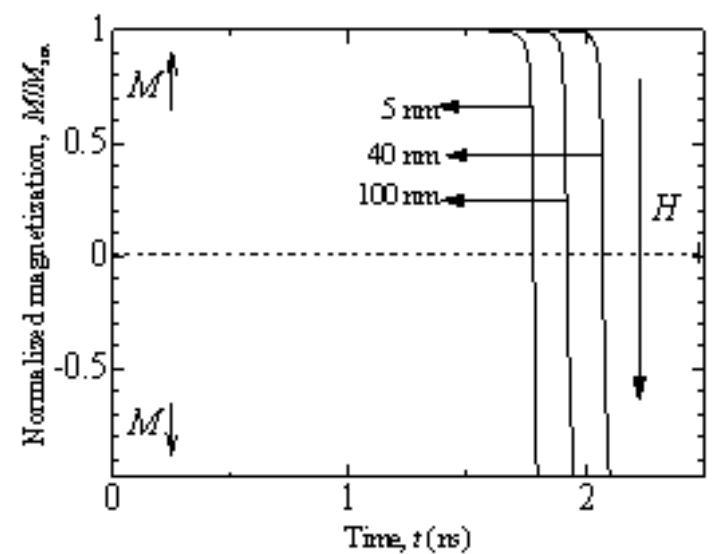

(a)

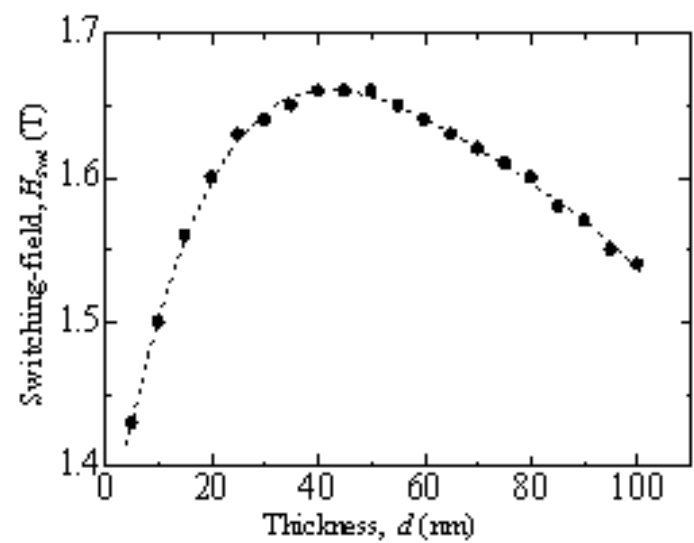

(b)

Figure 4. (a) The magnetization reversal of Barium-ferrite nano-dot for three different thicknesses $5 \mathrm{~nm}, 40 \mathrm{~nm}$, and $100 \mathrm{~nm}$, (b). The switching field of Barium-ferrite nano-dot for various thicknesses at room temperature.

The impact of the nano-dot thickness to the rate of nano-dot magnetization is shown in Fig.5(a). This rate tends to decrease exponentially along with the thickening of the nano-dot. Magnetization rate is highly sensitive to the thickness in the range of $5 \mathrm{~nm}$ up to $50 \mathrm{~nm}$. It means that more required time for thick nano-dot to be magnetized since its domain wall starts to nucleate. Meanwhile, magnetization rate tends to be constant over $45 \mathrm{~nm}$ of the thickness. This magnetization rate information is important for magnetic storage application which correlated to the efficiency of data recording. With fast magnetization rate, the utilization of this magnetic recording more efficient in time either energy consumption.

Visualization of magnetization mode for $5 \mathrm{~nm}, 40 \mathrm{~nm}$, and $100 \mathrm{~nm}$ of thicknesses is shown in Fig.5(b). Initial magnetization state which has uniform magnetic moments direction of nano-dot is represented as a black area. At this state, magnetic moments of a nano-dot lie in $\left(x^{+}\right)$direction. Meanwhile, white area represents the magnetization in the opposite direction (in line with the external magnetic field). There is a transition area between the black and white regions which colored as gray. This region is called as domain wall. This domain wall separates two opposite domains that exist in a nano-dot. During the increasing of magnetic field induction, the domain wall is nucleated at the center of nano-dot. This means, the effective field at the center is highest than other area and the exchange interaction between neighboring unit cells dominate the interaction (Azizah et al., 2016). After this nucleation, domain wall propagates extensively so that the white area dominates the nano-dot. It is the final state at which a single domain realized.

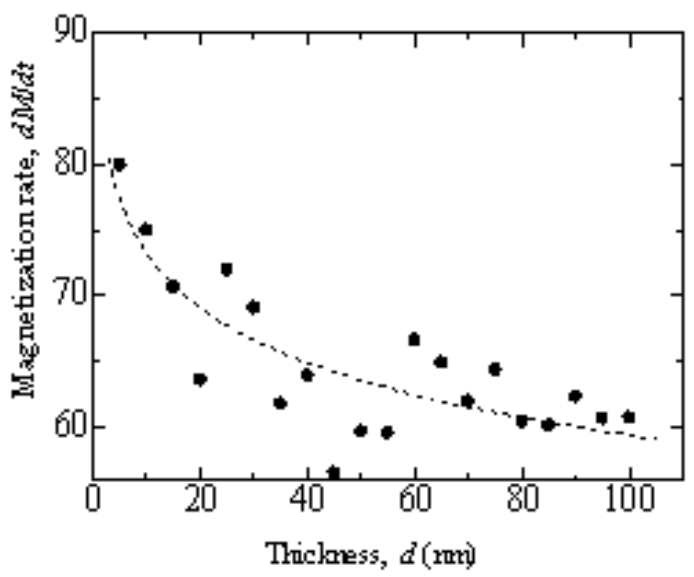

(a) 


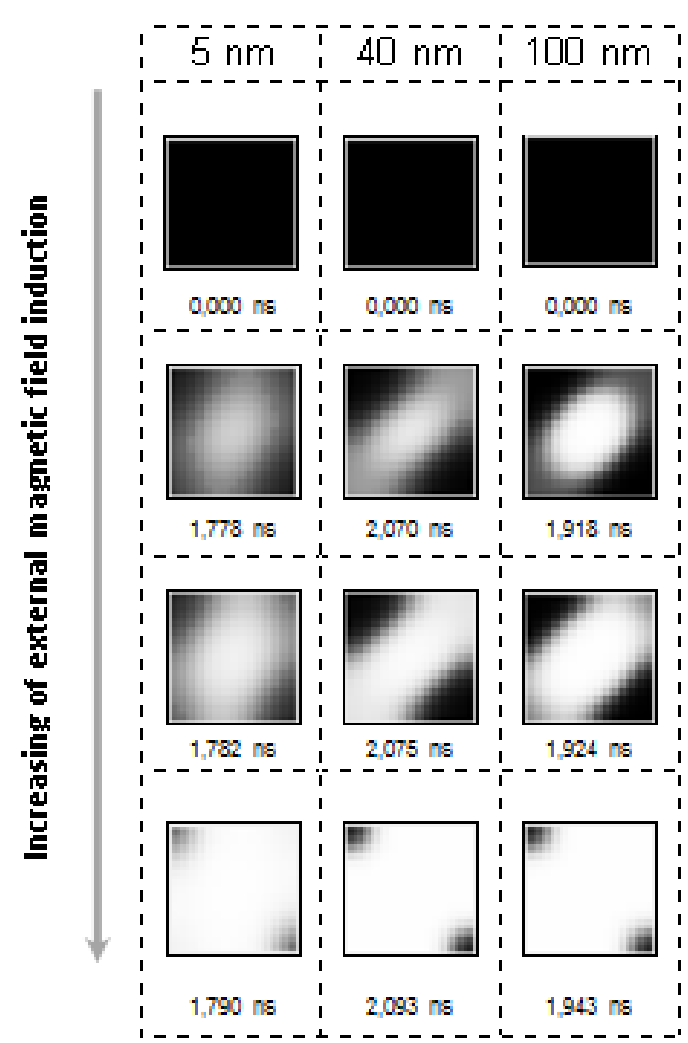

(b)

Figure 5. (a). The thickness dependence of the magnetization rate of the Barium-ferrite nanodot for various thicknesses at room temperature, (b). The visualization of magnetization reversal of Barium-ferrite nano-dot for three different thicknesses $5 \mathrm{~nm}, 40 \mathrm{~nm}$, and $100 \mathrm{~nm}$ during induced by external magnetic field.

\section{CONCLUSION}

Thickness dependence of the magnetization dynamics for Barium-ferrite nano-dot has been investigated using Landau-LifshitzGilbert equation. As a result, the Barium-ferrite nano-dot has the excellent thermal stability which represented by its high barrier energy (> $\left.60 k_{\mathrm{B}} \mathrm{T}\right)$ for entire the chosen thicknesses. Temporarily, the magnitude of the switching field reaches its maximum value at $40 \mathrm{~nm}$ of thickness then decrease along as the thickening of nano-dot. This switching field reduction is followed by the increasing of thermal stability level. Moreover, the fastest and slowest magnetization rates are observed for $5 \mathrm{~nm}$ and $45 \mathrm{~nm}$ of the thicknesses respectively. The magnetization reversal mode is dominated by domain wall nucleation and propagation which exchange interaction takes more noteworthy control than another contributed energies.

\section{ACKNOWLEDGMENTS}

This research was supported by Satya Wacana Christian University through Internal Funding 2016.

\section{REFERENCES}

Alebrand, S., Gottwald, M., Hehn, M., Steil, D., Cinchetti, M., Lacour, D., ... Mangin, S. (2012). Light-induced magnetization reversal of high-anisotropy TbCo alloy films. Applied Physics Letters, 101(16), 162408.

Augustine, C., Raychowdhury, A., Behin-Aein, B., Srinivasan, S., Tschanz, J., De, V. K., \& Roy, K. (2011). Numerical analysis of domain wall propagation for dense memory arrays ( $p$. 17.6.1-17.6.4). IEEE.

Azizah, U. M. N., Trihandaru, S., \& Wibowo, N. A. (2016). Micromagnetic study of exchange interaction effect on magnetization reversal mode of CoFeAl (p. 030014).

Cho, J., Jung, J., Cho, S.-Y., \& You, C.-Y. (2015). Effect of annealing temperature on exchange stiffness of CoFeB thin films. Journal of Magnetism and Magnetic Materials, 395, 18-22. https://doi.org/10.1016/j.jmmm.2015.06.073

Herianto, N. A., Rondonuwu, F. S., \& Wibowo, N. A. (2015). Damping Dependence of Reversal Magnetic Field on Co-based Nano-Ferromagnetic with Thermal Activation. Smart Science, 3(1), 16-20. https://doi.org/10.1080/23 080477.2015 .11665632

Hou, Y., \& Krishnan, K. M. (2012). Thickness-dependent magnetization reversal behavior of lithographic IrMn/Fe ring structures. Journal of Applied Physics, 111(7), 07B905. https:// doi.org/10.1063/1.3672827

Hui, Y., Cheng, W., Yan, P., Chen, J., \& Miao, X. (2015). Thickness dependence of magnetic properties in La?Co substituted strontium hexaferrite films with perpendicular anisotropy. Journal of Magnetism and Magnetic Materials, 390, 56-60. https://doi.org/10.1016/j. jmmm.2015.04.081

Jung, S.-W., Kim, W., Lee, T.-D., Lee, K.-J., \& Lee, H.-W. (2008). Current-induced domain wall motion in a nanowire with perpendicular magnetic anisotropy. Applied Physics Letters, 92(20), 202508. https://doi. org/10.1063/1.2926664

Kim, C., Loedding, T., Jang, S., Zeng, H., Li, Z., Sui, Y., \& Sellmyer, D. J. (2007). FePt nanodot arrays with perpendicular easy axis, large coercivity, and extremely high density. Applied Physics Letters, 91(17). https://doi. org/10.1063/1.2802038

Kim, J.-H., Lee, J.-B., An, G.-G., Yang, S.-M., Chung, W.-S., Park, H.-S., \& Hong, J.-P. (2015). Ultrathin $\mathrm{W}$ space layer-enabled thermal sta- 
bility enhancement in a perpendicular $\mathrm{MgO} /$ $\mathrm{CoFeB} / \mathrm{W} / \mathrm{CoFeB} / \mathrm{MgO}$ recording frame. Scientific Reports, 5(1). https://doi.org/10.1038/ srep16903

Krone, P. (2011). Magnetization Reversal Processes of Nanostructure Arrays (Dissertation). Retrieved from http://www.qucosa.de/recherche/frontdoor/?tx_slubopus4frontend $\% 5$ bid $\% 5 d=u r n: n b n: d e: b s z: c h 1-q u c o s a-71358$

Lisfi, A., \& Lodder, J. C. (2002). Relation between the microstructure and magnetic properties of BaFe12O19 thin films grown on various substrates. Journal of Magnetism and Magnetic Materials, 242-245, Part 1, 391-394. https:// doi.org/10.1016/S0304-8853(01)01233-1

Liu, Y., Yu, T., Zhu, Z., Zhong, H., Khamis, K. M., \& Zhu, K. (2016). High thermal stability in W/ $\mathrm{MgO} / \mathrm{CoFeB} / \mathrm{W} / \mathrm{CoFeB} / \mathrm{W}$ stacks via ultrathin $\mathrm{W}$ insertion with perpendicular magnetic anisotropy. Journal of Magnetism and Magnetic Materials, 410, 123-127. https://doi. org/10.1016/j.jmmm.2016.02.099

Ma, Y., \& Liu, B. (2008). Lube Depletion Caused by Thermal-Desorption in Heat Assisted Magnetic Recording. IEEE Transactions on Magnetics, 44, 3691-3694. https://doi. org/10.1109/TMAG.2008.2001670

Mansuripur, M., \& Connell, G. A. N. (1984). Energetics of domain formation in thermomagnetic recording. Journal of Applied Physics, 55(8), 3049. https://doi.org/10.1063/1.333298

Metaxas, P. J., Jamet, J. P., Mougin, A., Cormier, M., Ferré, J., Baltz, V., ... Stamps, R. L. (2007). Creep and Flow Regimes of Magnetic Domain-Wall Motion in Ultrathin Pt / Co / Pt Films with Perpendicular Anisotropy. Physical Review Letters, 99(21). https://doi. org/10.1103/PhysRevLett.99.217208

Mihai, A. P., Whiteside, A. L., Canwell, E. J., Marrows, C. H., Benitez, M. J., McGrouther, D., ... Moore, T. A. (2013). Effect of substrate temperature on the magnetic properties of epitaxial sputter-grown Co/Pt. Applied Physics Letters, 103(26), 262401. https://doi. org/10.1063/1.4856395

Purnama, B., Koga, M., Nozaki, Y., \& Matsuyama, K. (2009). Stochastic simulation of thermally assisted magnetization reversal in sub-100 $\mathrm{nm}$ dots with perpendicular anisotropy. Journal of Magnetism and Magnetic Materials, 321(9), 1325-1330. https://doi.org/10.1016/j. jmmm.2008.12.003

Purnama, B., Prihanto, H. S. B. R., Artono, D. S.
(2013). Karakteristik Magnetik Lapisan Tipis $\mathrm{Ni}$-Fe Sebagai Flat Core Flux Gate Sensor. Jurnal Pendidikan Fisika Indonesia, 9(2). https://doi.org/10.15294/jpfi.v9i2.3039

Sadnawanto, W., -, C., \& Purnama, B. (2014). Modifikasi Model Thermally Pada Heat Assisted Magnetisasi Reversal Nano Partikel Magnetik. Jurnal MIPA, 37(2), 136-140.

Schrefl, T., Fidler, J., Suess, D., Scholz, W., \& Tsiantos, V. (2006). Micromagnetic Simulation of Dynamic and Thermal Effects. In Y. Liu, D. J. Sellmyer, \& D. Shindo (Eds.), Handbook of Advanced Magnetic Materials (pp. 128-146). Boston, MA: Springer US. Retrieved from http://link.springer.com/10.1007/1-40207984-2_4

Shepley, P. M., Rushforth, A. W., Wang, M., Burnell, G., \& Moore, T. A. (2015). Modification of perpendicular magnetic anisotropy and domain wall velocity in $\mathrm{Pt} / \mathrm{Co} / \mathrm{Pt}$ by voltage-induced strain. Scientific Reports, 5, 7921. https://doi. org/10.1038/srep07921

Shimizu, O., Murata, Y., Kurihashi, Y., Harasawa, T., Asai, M., Sueki, M., \& Noguchi, H. (2012). Long-Term Archival Stability of Barium Ferrite Magnetic Tape. Journal of the Magnetics Society of Japan, 36(1_1), 1-4. https://doi. org/10.3379/msjmag.1112R001

Waseda, K., Doi, R., Purnama, B., Yoshimura, S., Nozaki, Y., \& Matsuyama, K. (2008). Heat-Assisted Magnetization Reversal Using Pulsed Laser Irradiation in Patterned Magnetic Thin Film With Perpendicular Anisotropy. IEEE Transactions on Magnetics, 44(11), 2483-2486. https://doi.org/10.1109/ TMAG.2008.2003068

Woo, S., Litzius, K., Krüger, B., Im, M.-Y., Caretta, L., Richter, K., ... Beach, G. S. D. (2016). Observation of room-temperature magnetic skyrmions and their current-driven dynamics in ultrathin metallic ferromagnets. Nature Materials, 15(5), 501-506. https://doi.org/10.1038/ nmat4593

Wood, R. (2009). Future hard disk drive systems. Journal of Magnetism and Magnetic Materials, 321(6), 555-561. https://doi. org/10.1016/j.jmmm.2008.07.027

Zhang, G., Li, Z., Wang, X., Nie, Y., \& Guo, G. (2015). Shape-tuned dynamic properties of magnetic nanoelements during magnetization reversal. Journal of Magnetism and Magnetic Materials, 385, 402-406. https://doi.org/10.1016/j. jmmm.2015.03.043 